\title{
Implementation of the polluter pays principle - example of planning for decommissioning
}

\author{
S. Lindskog ${ }^{1} \&$ R. Sjöblom ${ }^{2}$ \\ ${ }^{1}$ The Swedish Radiation Safety Authority, Sweden \\ ${ }^{2}$ Tekedo AB, Sweden
}

\begin{abstract}
The Swedish Radiation Protection Authority (SSM) and some of its predecessors have since the late nineteen seventies overseen the Swedish system of finance for decommissioning and waste management of nuclear facilities. This system contains segregated funds for the costs according to best estimate and securities to cover uncertainty.

Recently, the underlying legislation was extended to also include various small facilities with sometimes small businesses as owners, and the Government authorized the SSM to issue regulations as warranted and appropriate.

The implementation of the new legislation includes the challenges of simultaneously honouring the polluter pays principle and the principle of equity between the generations whilst at the same time complying with the requirements on proportionality as well as harmony with other legislation.

Surveys have therefore been conducted regarding similar solutions in other areas as well as statements in other legislations, and the results are briefly summarized in the present paper. Previous supporting work includes analyses of planning for decommissioning and cost calculation methodologies.

It is found that the estimated cost, prepared in accordance with the state of the art, can form the basis for the selection of means for financial assurance. Thus, exemption can be recommended for liabilities up to $\mathrm{k} € 2,4$, securities alone up to M€ 0,1, and securities in combination with segregated funds above this level.

It is commented that some ombudsman type of organisation is required to safeguard the interests of future generations with regard to environmental liabilities, and that advice may be received from the younger generation.
\end{abstract}

Keywords: decommissioning, nuclear, fund, security, Sweden, legislation, polluter pays principle. 


\section{Definitions}

There are three levels of legislation in Sweden:

\begin{tabular}{|c|c|c|c|}
\hline Legislation & Issued by & Compliance with & Authorized by \\
\hline Law & Parliament & Constitution & Swedish people \\
\hline Ordinance & Government & Laws & Parliament \\
\hline Regulation & Competent Authority & Laws and Ordinances & Government \\
\hline
\end{tabular}

* Such as the Swedish Radiation Safety Authority.

Laws, ordinances and regulations are legally binding and the compliance of them is overseen and assured by our legal system, including our courts.

In addition, a Competent Authority can issue general advice with regard to a certain regulation. It can contain clarification as to what the actual regulation is intended to mean and may also provide examples. General advice is not legally binding and compliance must not necessarily be upheld in a court decision.

Competent Authorities - like everybody else, e.g. a branch organization - can also issue guidance documents. They reflect good practice, but cannot necessarily be relied on for compliance with legislation.

In this paper, the Swedish Radiation Safety Authority (in Swedish: Strålsäkerhetsmyndigheten) is referred to by its abbreviated name, SSM. This paper refers to work in progress. Any conclusions represent the views of the authors.

\section{Introduction}

\subsection{Implementation of environmental legislation}

The last few decades have meant a shift of paradigm in that basic principles have been established and policies agreed on a number of environmental issues including protection of health and environment, conservation, re-cycling, sustainable development, remediation, use of best available technology, equity between generations and the polluter pays principle (PPP), also known as the Extended Polluter Responsibility (EPR).

Associated legislation has been issued and enforced. Releases to the environment - e.g. as fly ash and sulphur dioxide - have plummeted.

The success rate is very varied, however, and the following was written [1] in 1997 by Staffan Westerlund, professor of environmental law at the University of Uppsala (translation from Swedish by the present authors):

"It is well known that environmental laws seldom function well and that environmental goals are usually not achieved. We have also become accustomed to an almost total inefficiency of regulations intended to alter environmentally inappropriate behaviour. It does not come as a surprise that concrete rules ... still 25 years after having come into force have not been implemented and enforced. Over the years, there have been so many incidences of malfunctioning of the environmental legal system that we who teach law must make a quite clear 
distinction between on one hand the law as it is written,... and on the other hand how it actually functions (or actually does not function).",

Obviously, the prerequisites for implementation of general strategies and framework laws can vary enormously between different situations.

Cases are comparatively straightforward and easy where

- The potential polluter and its activities can be clearly identified;

- The impact on health and environment can readily be measured and assessed;

- $\quad$ The potential polluter needs a permit (with certain conditions);

- The potential polluter is competent and rational in the selection of the best available technology.

Cases are comparatively difficult, and even cumbersome, when the link between the polluter and the potential impact is difficult to establish, e.g. when the relations between cause and effect are not well understood. Another difficulty arises when remediation is to be done long after the corresponding industrial activity has been terminated. Implementation may be further impeded if, in addition, technical and thereby also financial planning is difficult to carry out long before the restoration is to take place.

Consequently, cases where the polluter pays principle is to be implemented simultaneously with the principle of solidarity between generations can be expected to be particularly daunting, especially if there are also obstacles to the planning process.

\subsection{Nuclear legacy legislation and its implementation}

All these challenges apply when these two principles are to be implemented for the case of decommissioning of old nuclear research facilities (and similar) in Sweden.

Previous legislation on financing of our nuclear legacy has included our ten nuclear power plants and certain major facilities from our nuclear technology development period (about 1955 to 1975). The new legislation, primarily in the form of an ordinance [2] that came into force on November $1^{\text {st }} 2008$, includes all nuclear facilities regardless of size. The ordinance also contains authorization from the Government to the SSM to issue regulation as warranted and appropriate for the implementation.

In addition to proper authorisation, our Constitution states a number of requirements that apply to any such regulation, including the following:

- A regulation must contain a reasonable balance between different interests, and the benefits must be justified in comparison with the costs for compliance. (The proportionality principle)

- $\quad$ All must be dealt with in an equal manner.

- There must not be any contradictions with any other legislation.

- There has to be a follow-up of the outcome, and adjustments made as appropriate from any lessons learned.

- A regulation must be simple and clear.

The first bullet in this list corresponds to the so-called proportionality principle which must be applied simultaneously with the other principles. 
The present work was prompted as a result of the above mentioned authorization from the Government.

\section{Purpose and scope}

The purpose of the present paper is to illustrate how the polluter pays principle and the principle of solidarity between generations can be implemented simultaneously even in cases where the planning is difficult.

The scope of this paper is to summarize the following

- the implementation of these principles in several areas

- relevant legislation

- $\quad$ prerequisites for financial planning for decommissioning of nuclear facilities

The scope is also to analyse this information for the purpose of implementation of the two principles. This will be carried out with small nuclear facilities as an example.

\section{Environmental liabilities in some areas}

\subsection{Forestry}

Legislation on preservation and protection of forest extends beyond written records, and statements to this end exist even in our oldest written law, the older Westgothia law [3], from around the year 1220.

Early environmental legislation includes the statement by our queen Kristina on March 18th 1639 when she banned burn-beating by the penalty of banishment. The wood from the forest had better use in our metals beneficiation industry.

The Swedish Forestry Act [4] was first issued in 1903, at around which time our forests were being converted from primeval (old-growth) forests to forests that are actively managed (including recurrent replanting). The law states that the owner must replant after harvest. When harvested forest is sold, the seller may have to guarantee that the buyer will replant by means of securities.

\subsection{Mining, beneficiation and contaminated soil}

Our first record of a mining stock company relates to the Falun copper mine and is from the year $1288[5,6]$. The roasting of this sulphide ore gave rise to enormous emissions of sulphur dioxide, as has been witnessed by many travellers including Carl von Linné (who developed a system for the categorization of plants). The smoke was bothersome to the miners and was disastrous to the crops around, but had the advantage that plague never reached the area. At least during most of the $17^{\text {th }}$ and $18^{\text {th }}$ century there was a constant legal battle between the miners and the farmers on the emissions, and for long periods of time ore could be roasted only outside the growing season. 
There are many old mine tailings and associated contaminated soil in Sweden that need remediation. Contaminated soil has also come about as a result of many other activities. At present, annual public spending in Sweden on remediation of old mine tailings and contaminated soil exceeds M€ 50. According to the website of our Environmental Protection Agency (in Swedish: Naturvårdsverket) this is insufficient even to remediate those sites associated with the highest risks before the year 2050 .

For present day industrial activities, the legal entities associated with mining and beneficiation activities are fully responsible for any remediation required. Copper ore is no longer mined at the Falun site, but at Boliden and Aitik. According to the Annual Report for the year 2008 of Boliden AB (AB is an abbreviation of the Swedish word "Aktiebolag" which means limited stock company), the Competent Authority has received guarantees for around M€ 50 to cover the environmental liabilities for the restoration associated with the Aitik mine alone.

Especially residues from mining of sulphide ores have the potential of causing increased releases over time as a result of the acidification that takes place if and when the residues come in contact with the oxygen in the air.

The heap of shale ash at Kvarntorp near Örebro constitutes an example of such a situation. It is a hundred metres high and comprises several tens of million tonnes of material. The ash was generated during 1940 and 1965 when oil was extracted from the shale. Much of the carbon and sulphur in the shale was left un-combusted in the processes. The residues are burning still today, and for this reason, the heap is kept dry and the releases are low. If no remedial action is taken, the heap will cool sooner or later, and it can then be feared that acidification takes place and the releases become substantially increased.

At the same time, it should be realized that there is a substantial difference between on one hand the cautious modelling made in order to ensure that environmental impact is acceptable, and on the other hand realistic modelling. The streams and lakes surrounding the Falun copper mine mentioned above have a surprisingly healthy biological life [5].

\subsection{Offshore}

There are no offshore rigs for oil production in the Swedish waters, and consequently no associated domestic need for decommissioning and restoration.

Internationally, offshore is one of the major areas of environmental liabilities. It is no longer acceptable to just tow a scrap rig to deeper waters and sink it. Instead, all structures above the bottom of the sea have to be taken ashore and either be recycled or deposited in a landfill.

The decommissioning is organized somewhat differently as compared to other areas. Oil rigs represent enormous investments whilst the return in terms of oil production may be variable. Consequently, even large oil companies often own and operate oil rigs through consortia. In concordance, planning for decommissioning as well as issuing of financial assurances to Competent Authorities are also carried out through consortia based on consortia agreements. 
Offshore decommissioning includes the challenges of deep water work with aged and possibly deteriorated large structures. However, most of the material retrieved is recycled, and residues are deposited mainly in ordinary landfills. Thus, offshore decommissioning does not have to deal with such sometimes large uncertainties that are associated with the decommissioning of nuclear facilities and their associated radioactivity, nor does it have to take responsibility for long-term events in waste repositories such as may be the case for mining residues, contaminated soil and nuclear waste.

Much of the information presented above on offshore decommissioning has been obtained through a membership of one of us with the Norwegian Petroleum Society (In Norwegian: Norsk Petroleumforening), see www.npf.no.

\subsection{Nuclear technology}

Sweden was one of the six countries that took part in the rush to build the first nuclear power stations. The other countries were United States, United Kingdom, France, Soviet Union and Canada. All other countries with nuclear power reactors have had to turn to either of these for assistance [7]. Our first nuclear power plant was taken into operation in 1963 as a result of a comprehensive research and development (R\&D) programme. The contributions to this programme from the Government alone (during the years 1955-1975) amounted to a total of around G€ 1,55 in today's currency [8]. Most of the R\&D work was conducted in the facilities at Studsvik, see Figure 1 [9-13].

The first controlled chain reaction took place in 1942, almost 50 years after the x-rays (= gamma rays) had been discovered. The hazard associated with radiation (e.g. cancers many years after exposure) was well known at that time, but there was no experience with induced radioactivity. It took until the mid seventies until nuclear waste research caught on speed. According to the national implementer of this R\&D programme, the Swedish Nuclear Fuel and Waste Management Company, SKB, the accumulated R\&D cost until present at the price level of today is about G€ 1,90 (see www.skb.se). This research covers the waste from our ten nuclear power plants in operation and three taken out of service as well as the waste from research and development.

Old literature, see e.g. "the architect in the nuclear age" from 1964 makes no or little mentioning of the implications of induced radioactivity for decommissioning of a facility [9]. Actually, decommissioning may be even more expensive than building a facility, especially if no precautions were taken initially.

The total cost for decommissioning and waste management of the facilities in Figure 1 is presently estimated to around $0,2 \mathrm{G} €$. This includes the cost for decommissioning of the Active Central Laboratories which might be estimated to around $\mathrm{M} € 10$ (no final report is known to the authors). The estimates on the costs remaining in 1998 have varied up to a factor around three, largely due to difficulties in assessing the varying alpha contamination in the absence of good fingerprint gamma emitters [14-16]. 


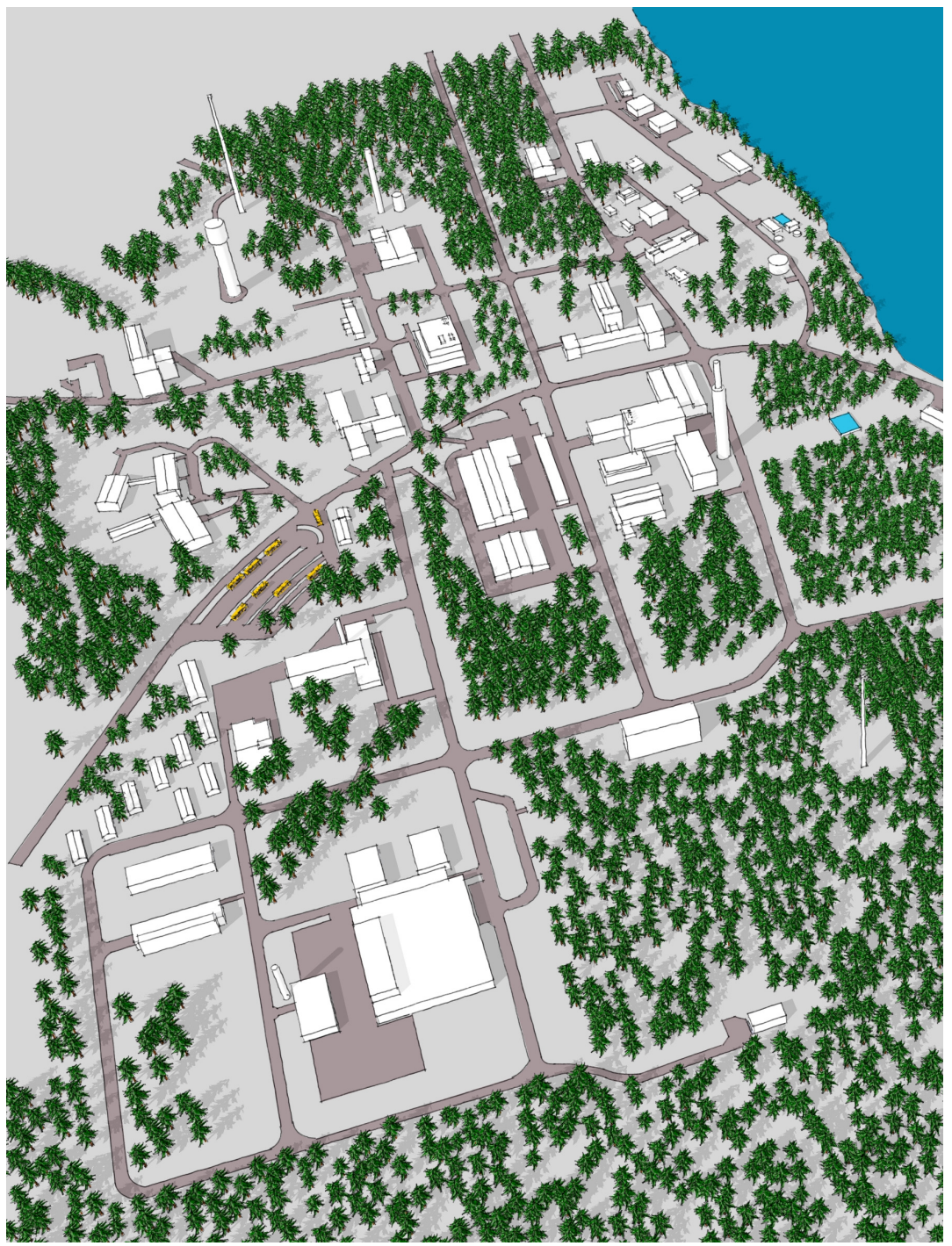

Figure 1: Artist's impression of the Studsvik site (about 80 kilometres south of Stockholm) at around the year 1965. The illustration is based on contemporary drawings [9, 10] and areal photographs [10-13]. (The site looks substantially different today.) The size of the site is approximately 1,0 by $0,7 \mathrm{~km}^{2}$. The lower middle block contains the two buildings that comprised the Active Central Laboratories (ACL). It has recently been decommissioned to green field conditions, cf text. The laboratory was built for mixed oxide (uranium + plutonium) fuel fabrication on a laboratory and a pilot scale, but equipment for the latter was never installed. 
The total nuclear legacy in Sweden is at present estimated to about G€ \#. The uncertainty (in \%) is much larger for small and old facilities as compared to new and large ones. The costs are to be covered by two segregated funds, one for the 12 modern nuclear power plants (NPPs) and one for most of the old facilities from the era of nuclear technology development. The funds also have securities to cover uncertainty.

\section{Legislation}

\subsection{Nuclear technology legislation}

Nuclear safety is primarily regulated in Sweden by and under two laws: The Radiation Protection Act [17] and Act on Nuclear Activities[18]. The Radiation Protection Act applies generally to radiation.

The Act on Nuclear Activities is valid for facilities in which nuclear chain reactions take place and related facilities. It is also valid for nuclear material (i.e. material that is fissile or can be activated to become fissile), for activated material (with several exceptions), and for nuclear waste.

The Nuclear Liability Act [19] is valid for nuclear material that is not intended to be reused and for nuclear waste that is not waste from daily operation.

As already mentioned, there are two "compartments" for securities and fees to segregated funds:

A the anticipated costs for decommissioning and waste management etc, and

B a risk fee intended to cover the risk that the Government takes in its management of the fund system.

Compartment A comprises a combination of securities and assets in segregated funds. Securities are lifted at the same pace as that of the payments that flow into the segregated funds.

The new ordinance [2], issued by the Government under the Nuclear Liability Act [19], states that those eligible under the law who are not nuclear power reactor owners are obligated to submit to SSM every third year a cost calculation comprising the following:

- the total best estimate for the cost for decommissioning and waste management,

- the expected remaining time of operation,

- the proposed proportions between securities and assets in a segregated fund.

Subsequently, the SSM will review the material and decide on the fee to be paid.

The new ordinance has also granted the SSM authority to decide on exemption from requirements on securities as well as on payments to segregated funds. 


\subsection{The Swedish environmental code}

The Swedish Environmental Code states [20] as follows: "Persons who pursue or have pursued an activity or taken a measure that causes damage or detriment to the environment shall be responsible, until such time as the damage or detriment ceases, for remedying it to the extent deemed reasonable ...". The Code also states that permits issued under the code may be associated with requirements on securities corresponding to all future costs.

\subsection{Financial reporting legislation}

The laws covering financial reporting for ordinary companies in Sweden are primarily the Accounting Act [21], Annual Reports Act [22] and the Swedish Companies Act [23]. The Accounting Act states in $\S 2$ that the obligation of book-keeping must be carried out in accordance with "good practice".

Large companies are obligated to follow the International Financial Reporting Standards and International Accounting Standards (IFRS/IAS) [24] while small companies may follow the general advice issued by Swedish Accounting Standards Board (in Swedish: Bokföringsnämnden, BFN) [25].

\subsection{Criminal law}

The Swedish Penal Code[26] is the same for all. It states that anyone who is obligated to follow the Accounting Act [21] but declares figures that are not correct so that the books no longer present an "essentially correct financial situation" may be sentenced to jail for at most six years (in severe cases).

There is a clear possibility that errors and uncertainties in estimations of decommissioning costs may be large in comparison with the errors and uncertainties for other posts in financial books. Compliance might be evaluated using the Elofsson method, according to which an acceptable deviance may be at most $30 \%$ [27].

\section{Example of small nuclear facilities}

It was mentioned in Section 2.2 that the new ordinance [2] authorizes the SSM to issue regulation as warranted and appropriate for its implementation. The ordinance also refers to present and previous holders of permits under the Act of Nuclear Activities [17], but leaves it to the SSM to regulate what tools to apply and to differentiate between them.

It might be tempting to assume that such selections should be based on the complexity of the nuclear activity that has taken place in any particular facility. Indeed, it can be concluded that the decommissioning of a nuclear facility would be quite trivial if only sealed sources have been handled or if all radioactivity has been short-lived. Such cases could warrant exemption. Otherwise the relation has been found to be weak, however.

Instead, it has been found that differentiation between funds, securities and exemption can be based on estimations of the cost for decommissioning. As has 
been briefly illustrated above, such costs have proven notoriously difficult to estimate with any accuracy, especially for old research facilities. It has been found, however, that a precision of $\pm 15 \%$ might be attained, at least in favourable cases, if adequate planning is carried out. The prerequisites for this were presented at the previous meeting on Environmental Economics [28], see also [16, 29-33] and references therein.

Such planning is required already under the financial laws (cf Section 5.3) and the penal law (cf Section 5.4). To use estimated costs as a basis for selection between funds, securities and exemption does thus not impose any new or further burden on the facility owners. It is therefore the alternative put forward in the present study. It is also suggested that the upper limit for exemption be set at around $\mathrm{k} € 2,4$ and the upper limit for securities alone at around $\mathrm{k} € 100$.

The Nuclear Liability Act [19] as well as the new ordinance [2] regulate how financing of decommissioning is to be carried out in general and specifies that segregated funds supplemented by securities are to be used.

\section{Final comments}

Application of the polluter pays principle simultaneously with the principle of equity between generations requires considerably more complex considerations than e.g. a release limit in that adequate attention need to be applied in several areas simultaneously. In the example above of decommissioning of small nuclear facilities, the timing of the planning is largely dictated by the needs of the system of finance.

It might be tempting to consider that such a sustainable approach is a modern innovation. However, according to the Westgothia law [3], land belonged to the clan and was to be passed over to the sons and daughters when they married. It could be sold outside the clan only after consent from the relatives together with a court ruling. Instead, the quarterly report syndrome - where company managements follow the whims of institutional investors rather than the longterm prerequisites - seems to be a modern phenomenon.

Research suggests that an individual will sacrifice consumption to benefit future generations only if the guarantee exists that others will also do so [34].Thus, modern bodies are needed for the ancient tasks of the clan and the court. Such solutions are proposed in Reference [34].

It is important in this regard to realize that we do have access to the values of one future generation, namely the young generation, see a separate paper to the present conference[35].

\section{References}

[1] Westerlind, S., A legal system for sustainable development. (In Swedish: En hållbar rättsordning). Justus förlag, Uppsala 1997. ISBN 91-7678-372-3.

[2] Ordinance on financial action for the management of residues from nuclear technology activities. (Förordning om finansiella åtgärder för hanteringen av restprodukter från kärnteknisk verksamhet, in Swedish). SFS 2008:715. 
[3] The older Westgothia law. (In Swedish: Äldre Västgötalagen, översatt och förklarad av Nat. Beckman). Appelbergs Boktryckeri Aktiebolag, Uppsala, 1924.

[4] The Swedish Forestry Act. (In Swedish Skogsvårdslagen). SFS 1979:429.

[5] Lindeström, L. The environmental history of the Falun Mine. Almqvist \& Wiksell Tryckeri, Uppsala 2003. ISBN 91-631-3536-1.

[6] Lindroth, S., Mining and copper beneficiation at the Great Copper Mountain. (In Swedish: Gruvbrytning och kopparhantering vid Stora Kopparberget). Almqvist \& Wiksell Boktryckeri AB, Uppsala 1955.

[7] Controlled nuclear chain reaction, the first 50 years. American Nuclear Society, 1992. ISBN 0-89448-557-1.

[8] Fjæstad, M., \& Jonter, T., The Rise of the Nuclear System of Innovation in Sweden. Svenska ekonomisk-historiska mötet i Stockholm 2007.

[9] Munche, J-F., The architect in the nuclear age. Design of buildings to house radioactivity. Iliffe Books Ltd., London, 1964.

[10] Studsvik, Swedish research establishment. EuroNuclear, September, 1965.

[11] Österlundh, C. G. \& Erwall L. G., Erzeugung und Anwendung von Radioisotopen. (In German; Production and use of radioisotopes) Die Atomwirtschaft, February, 1963.

[12] Aler, B., Survey of Sweden. Nuclear Engineering International, September 1970.

[13] Bladh, R., and Eriksson, O., 40 år I Studsvik. (In Swedish; 40 years at Studsvik). Studsvik AB. ISBN 91-7010-283-X.

[14] Jonsson, B., Bergström, L. \& Lindberg, M., Decommissioning of the ACL and ACF plants in Studsvik, Sweden. Waste Management '04 Conference, February 29 - March 4, 2004, Tucson, Arizona, USA.

[15] Hedvall, H. R., Stridsman, K. H., Berg, R. S. \& Johnsson, B., Project evaluation of the decommissioning of a laboratory plant at Studsvik. Waste Management '06 Conference, February 26 - March 2, 2006, Tucson, Arizona, USA.

[16] Lindskog, S. \& Sjöblom, R., Radiological, technical and financial planning for decommissioning of small nuclear facilities in Sweden. Proceedings of the 12th International Conference on Environmental Remediation and Radioactive Waste Management, ICEM2009, October 11-15, 2009, Liverpool, UK.

[17] Act on Nuclear Activities. (In Swedish: Lag om kärnteknisk verksamhet). SFS 1984:3.

[18] Radiation Protection Act. (In Swedish: Strålskyddslag). SFS 1988:220.

[19] Nuclear Liability Act. (In Swedish: Lag om finansiella åtgärder för hanteringen av restprodukter från kärnteknisk verksamhet). SFS 2006:647.

[20] The Swedish Environmental Code. English translation. Ds 2000:61. (In Swedish Miljöbalk, SFS 1998:808).

[21] Accounting Act. (In Swedish: Bokföringslag). SFS 1999:1078.

[22] Annual Reports Act. (In Swedish: Årsredovisningslag). SFS 1995:1554

[23] The Swedish Companies Act. (In Swedish: Aktiebolagslagen). SFS 2005:551. 
[24] International Financial Reporting Standards and International Accounting Standards (IFRS/IAS). International Accounting Standards Board. 2008.

[25] Bokföringsnämndens allmänna råd om årsredovisning $i$ mindre aktiebolag. (General advice on annual reporting in small companies issued by the Swedish Accounting Standards Board, In Swedish).

[26] The Swedish Penal Code. (In Swedish: Brottsbalk). SFS 1962:700.

[27] Dahlqvist, A-L. \& Elofsson, S., Crimes in accountance and the law. (Swedish title: "Bokföringsbrott och bokföringslagen"). Norstedts juridik, Stockholm, 2005. ISBN 91-39-10709-4.

[28] Lindskog, S., Cato, A. \& Sjöblom, R., Estimations of costs for dismantling, decommissioning and associated waste management of nuclear facilities, and associated impact on decision processes, functioning of markets and the distribution of responsibilities between generations. Environmental Economics II, 28-30 May 2008, Cadiz, Spain. WIT Transactions on Ecology and the Environment, Vol 108. Wit Press, 2008. ISBN 978-184564-112-2.

[29] Lindskog, S. \& Sjöblom, R., Regulation evolution in Sweden with emphasis on financial aspects of decommissioning. Decommissioning Challenges: an Industrial Reality? Sept. 28 to Oct.2, 2008 - Avignon, France.

[30] Iversen, K., Salmenhaara, S., Backe, S., Cato, A., Lindskog, S., Callander, C., Efraimsson, H., Andersson, I. \& R. Sjöblom, R., Cost calculations at early stages of nuclear facilities in the Nordic Countries. The 11th International Conference on Environmental Remediation and Radioactive Waste Management. September 2-6, Bruges (Brugge), Belgium.

[31] Sjöblom, R., Sjöö, C., Lindskog, S. \& Cato, A., Early stage cost calculations for determination and decommissioning of nuclear research facilities. The 10th International Conference on Environmental Remediation and Radioactive Waste Management. Glasgow, UK, 4-8 September, 2005.

[32] Cato, A., Lindskog, S. \& Sjöblom, R., Financial Planning as a Tool for Efficient and Timely Decommissioning of Nuclear Research Facilities. American Nuclear Society. Decommissioning, Decontamination and Reutilization. Capturing Decommissioning Lessons Learned. September 16-19, Chattanooga, Tennessee, USA.

[33] Laraia, M. \& McIntyre, P. J., responsible officers; Cato A., Lindskog S. \& Sjöblom. R. et al contributors. Decommissioning of research reactors and other small facilitiesby making optimal use of available resources. IAEA Report Series 463, Vienna 2008.

[34] Padilla, E., Intergenerational equity and sustainability. Ecological Economics 41 (2002) 69-83.

[35] Labor, B. \& Lindskog, S., Values held by young stakeholders on financial planning regarding liabilities for nuclear decommissioning. Environmental Economics III, 3-50 May 2010, Cyprus. WIT Transactions on Ecology and the Environment. 